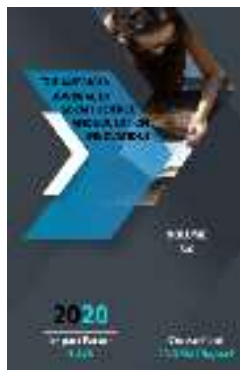

\title{
Abdurauf Fitrat's Views On Ecological Culture
}

\author{
Gulomov Akramjon Bakhromovich \\ Lecturer, Fergana State University, Fergana, Uzbekistan
}

Journal Website: http://usajournalshub.c om/index,php/tajssei

Copyright: Original content from this work may be used under the terms of the creative commons attributes 4.0 licence.

\section{ABSTRACT}

The article focuses on the analysis of the views of one of the representatives of the Jadid movement in the works of Abdurauffitrat on the conservation of nature, the promotion of ecological culture among the people in the common historical and modern.

\section{KEYWORDS}

Jadid, ecological culture, waste, cleanliness, healthy life, the story of an Indian tourist, Medicine (dorush-shifo)

\section{INTRODUCTION}

The environmental reforms being carried out in our country today require consistent and continuous changes in the field of education. It requires creative changes in the field of training in accordance with world standards. To this day, our creative people have been using the national heritage of our ancestors and our people for the development of our country by studying the ancient values, traditions and customs. In world science, scientific and theoretical research is being conducted on the ethno-ecology of peoples, the harmonization of ethno-esthetic relations with natural phenomena and daily life, the reflection of ecological consciousness and culture in the culture of peoples. 
"The most important thing is to seriously consider raising the environmental awareness of the population. .... this can be achieved in the hearts of the younger generation by bringing up with a love for mother nature and a sense of belonging to it." [1] Therefore, along with the improvement of educational and advocacy activities in the field of ecology in the country, there is an objective need to develop and develop a scientific and theoretical basis for the restoration and development of the values of the Uzbek people's ecological culture.

In accordance with the Decree of the President of the Republic of Uzbekistan No. PF-5863 dated October 30, 2019, the Resolution on approval of the Concept of environmental protection of the Republic of Uzbekistan until 2030 sets a number of tasks in the field of environmental protection, rational use of natural resources, sanitation and improvement was given. [2] According to him, the formation of ecological culture of the population, increasing the level of transparency of government agencies in the field of environmental protection and strengthening the role of civil society, the formation of a youth-friendly attitude to the environment, nature conservation, air, water and soil pollution, were given the task of further accelerating the processes aimed at preventing damage to flora and fauna.

It should be noted that the formation of ecological culture in our country can convey the culture of caring for nature through the views of Eastern thinkers on environmental education. One of the effective means is to provide young people with environmental knowledge and to study and analyze the current state of formation of educational theoretical knowledge related to the environment, as well as to organize the teaching of the rich cultural heritage left by our scientists.

\section{MATERIALS AND METHODS}

At the beginning of the twentieth century, a new social movement emerged in the Turkestan region, a socio-political movement known and popular as Jadidism. Much attention has been paid to the opening of new method schools under the Jadidism Action Plan. Although the political, social, cultural, and educational perspectives of the representatives of this movement have been extensively studied, their views on environmental culture, one of the most pressing issues for history and today, are poorly studied. Based on the above considerations, the object of our article is to analyze the historical and modern commonalities of the views of the Jadid movement on the ecological culture. One of the representatives of the Central Asian Jadid movement is AbduraufFitrat.

His works, such as The Debate and The Story of an Indian Traveler, focus on cleanliness in the villages and towns of Turkestan and the Emirate of Bukhara. In his moral work "Leadership Salvation" he elaborates on his views on cleanliness and environmental education. The great scholar Fitrat believes that cleanliness is important, especially in the upbringing of children, for their maturity and health. Fitrat argues that delicacy and cleanliness are of great importance in the upbringing of children. It is said that elegance and cleanliness are ten times more important to the little ones than they are to the older ones. He emphasizes that children should strictly follow the rules of personal hygiene. "The importance of fresh air in the upbringing of a child is more important for a person than food," he said. It is possible to stand without food for five or six hours, but it is also 
impossible to stand without air for a minute. That is why it is necessary to take children to the fresh air, to the gardens "[3]. In his philosophical views, AbduraufFitrat calls on children to love and care for the environment. In his textbooks and manuals, he conveyed many philosophical ideas about nature to students in modern schools.

Fitrat's story "The Indian Traveler" tells the story of an Indian Muslim tourist who came to Bukhara. In fact, the Indian tourist is the author himself. In the play, he speaks about the culture, medicine, industry and even the use of the underground resources of the Bukhara state for the benefit of the people, the spiritual and material wealth of the country. Fitrat speaks in the language of an Indian tourist about the cleanliness and health of Bukhara, and the need to open a medical school in the city. In the play, in the image of a Russian doctor, Fitrat expresses the idea that his countrymen should be seen as cultured, clean and educated, as in European countries. [4] In Fitrat's The Story of the Indian Traveler, the conservation of nature for that period raises issues that need to be addressed globally, not within Movaraunnahr. He expressed the following opinion about the efficient use of the lands of the Emirate of Bukhara: "If these lands of Shakhrisabz were in the hands of the Japanese, they would plant and produce gold." [5] In addition, in his scientific pamphlets, the scientist laments the need to keep the air clean in the streets of Bukhara. First of all, they land on our food, especially fruits, so they need to be washed and eaten. Fourth, it enters us as we breathe and settles in one of our internal organs. The solution is to keep the city streets clean and the air clean. You will be amazed to see the wide and clean streets of Farang and Russia, and none of them will bite your lips, none of them for eye-painting, but their governments have appointed the right, necessary law for this. Unfortunately, the filth of our streets makes us hate so much that we are powerless in the image. However, the cleanliness of cities is important for the life of every nation. [6]

Fitrat's broad outlook, his grief for his country, is a testament to his ability to understand his people and country very deeply. We can see that such ideas are related to artificial irrigation in the East, and that it is the basis of ecological education, the base of culture. The main content of our article is to read the teachings of Fitrat, which created ecological education, and thus enrich our knowledge, to master as much as possible his views on education, especially ecological education, and to pass it on to future generations.

\section{RESULT AND DISCUSSION}

Today, we are concerned about the protection of nature, emphasize the need for efficient use of mineral resources, and sign a number of decisions to protect the environment. Fitrat, in his The Story of the Indian Traveler, raised the topical idea of nature conservation as an intellectual of his society at that time. The play argues that "these resources, that is, the subsoil resources of Movaraunnahr, should be used in a clean and tidy manner, with the help of factories and machines." [7]

The peoples of Central Asia, including the Uzbek people, adhere to a culture of austerity in all circumstances. This applies to all products of labor, to everyday life. Among the people, this culture is called "uvol" for short. Surfing and overuse of natural resources such as water, soil and plants is also a waste. Unethical practices, such as overeating, overuse of natural resources, and weeding, are all evils. That is why AbduraufFitrat wrote in his time, urging everyone to be vigilant: "A nation whose representatives are afflicted with the disease of waste will undoubtedly perish. If you look at the history of the world, one of the 
reasons for the extinction of the peoples of the world is this extravagance. "[8]

This concept, which is becoming less and less used today, applies equally to all strata of people, regardless of who they are. Not wasting, not overdoing, not saving, is not a sign of greed as some think. Savings are a sign of a high level of spiritual culture.

It is a great sin for the Uzbek people to pollute water, especially to spit on it. Just as every habit has a root cause, this habit has its own causes. Today, when drinking water is one of the biggest problems, we can achieve certain results if we restore our ancient traditions, experiences, and culture of communication with nature. [9]

In his works, we can see Fitrat's ideas on how to keep well water clean, how to keep water and soil free of germs, and how to keep people healthy through the cleanliness of city streets. he following ideas are found in the scientific treatises of the scholar. "Canals in the city, especially in our city, run under the canals, wells and pools are open, hand water is not controlled and the places are definitely the origin of various microbes. If you dig a well in a clean place, keep it clean, and cover it all the time, you can drink the water without hesitation. The rule of medicine undoubtedly confirms that the cause of malaria and the Bukhara ring is the water of Bukhara. Harmful microbes pass from water to humans in several different ways. First of all, it goes through drinking water. We Turkestans collect water in pools near their aunts, wash their faces, hands, feet, blow their noses on one side and satisfy our thirst with pleasure on the other!" [10]

\section{CONCLUSION}

In conclusion, the respect for nature, the glorification of the land is reflected in the Eastern Uzbek wisdom, rules, doctrines, philosophical views, national values, national customs and traditions, passed down from generation to generation, from ancestors to generations. By studying the views of the Jadids on ecological culture, which formed an important stage in the history of the Uzbek people, we can identify the relationship between nature and man, the nature of their interconnectedness and unity, the environment, the causes of environmental problems and environmental culture and ecology. we can achieve elimination by shaping consciousness.

From the conclusions of our article we have developed the following suggestions and recommendations.

- The need to study the traditions of the people, formed on the basis of the harmony of nature and culture, as a natural and spiritual value and to promote them as an important factor in environmental education and to include them in school textbooks;

- To study the evolution, development, traditions and practices of the ecological culture of the Uzbek people, which have come down to us from ancient times, to summarize the achievements in this area and to share scientific pamphlets.

\section{REFERENCES}

1. MirziyoevSh.M. We will resolutely continue our path of national development and raise it to a new level. Tashkent: NMIU "Uzbekistan", 2017.- B. 570.

2. https://lex.uz/docs/4574008 President of the Republic of Uzbekistan 
Decree of the Republic of Uzbekistan on approval of the concept of environmental protection until 2030.

3. A. Fitrat "The Story of an Indian Traveler" Oriental Star Magazine, Issue 8, 1991, page 7.

4. That work is 8 pages.

5. That work is 9 pages.

6. Fitrat, Abdurauf. Selected works: 5 volumes. - T .: Manaviyat, 2010. - 167 p.

7. That work is 10 pages

8. Fitrat, Abdurauf. Selected works: 5 volumes. - T .: Manaviyat, 2010. - $136 \mathrm{p}$.

9. Z.Sh.Yazdonov Trends in the restoration and development of the traditions of Uzbek folk ecological culture / abstract of the dissertation for the degree of Doctor of Philosophy (PhD) Samarkand - $201916 \mathrm{p}$

10. Fitrat, Abdurauf. Selected works: 5 volumes. - T .: Manaviyat, 2010. - 168 p.

11. Mirzaraximov, B. X. (2019). Cultural Tourism Kak Strategy Razvitiya Knigovedeniya. Inperspective Oblasti Rasvitiya Nauki I Technologiy (Pp. 57-58).

12. Mirzarahimov, B. (2019). The factor of good neighborhood and tourism development (Philosophical analysis). Scientific Bulletin of Namangan State University, 1(1), 140-145.

13. Mirzarahimov, B. H. (2020). The Tasks Of Tourism In Aesthetic Education: The Harmony Of Historicity And Modernity. The American Journal of Social Science and Education Innovations,2(09), 652-658. 